\title{
Monitoring Progress of Change: Implementation of Education for Sustainable Development (ESD) within Documents of the German Education System
}

\author{
Jorrit Holst $^{1, *}$, Antje Brock ${ }^{2}$, Mandy Singer-Brodowski ${ }^{2}$ (D) and Gerhard de Haan ${ }^{2}$ \\ 1 Leipzig University, 04107 Leipzig, Germany \\ 2 Institut Futur, Freie Universität Berlin, 14195 Berlin, Germany; brock@institutfutur.de (A.B.); \\ s-brodowski@institutfutur.de (M.S.-B.); g.dehaan@fu-berlin.de (G.d.H.) \\ * Correspondence: j.holst@studserv.uni-leipzig.de
}

Received: 26 April 2020; Accepted: 20 May 2020; Published: 25 May 2020

check for updates

\begin{abstract}
Education for Sustainable Development (ESD) contributes to a holistic transformation of education systems, fostering deeply rooted learning processes required to co-create a sustainable future for all. The independent project National Monitoring on ESD in Germany traces the status and progress of formal ESD implementation via repeated large-scale indicator-based document analysis. Including over 4500 documents from early childhood education, school education, higher education, and vocational education and training, this study shows that the process of ESD implementation gained momentum over the period of the Global Action Programme (2015-2019). At the same time, large discrepancies remain between the areas of education, different types of documents, federal states, and with regard to the depth and quality of the contextualization of ESD and related concepts. While considerable developments are identifiable within all four formal areas of education, strong additional efforts are required for a comprehensive structural implementation of ESD in Germany. Although the results of the study focus on the status and progress of ESD within the German education system, the methodological framework may also serve as groundwork for other independent, comprehensive, and supportive monitoring programs.
\end{abstract}

Keywords: education for sustainable development (ESD); monitoring and evaluation; document analysis; governance; transformation; early childhood education; school education; vocational education and training; higher education; environmental education

\section{Introduction}

Twenty-first century societies face the challenge of having to rapidly transform towards sustainability while balancing the complex trade-offs between its ecological, social, and economic aspects [1-3]. To reconcile human well-being and the integrity of geo-bio-chemical processes necessary for all life on Earth, deeply rooted learning processes are required with regard to abilities, knowledge, and values [4,5]. Following the definition of UNESCO, Education for Sustainable Development (ESD) aims for a holistic transformation of education systems in order to foster such learning processes [6]. To equip people with the capabilities required to co-create a sustainable future for all, ESD addresses the "learning content and outcomes, pedagogy and the learning environment. It achieves its purpose by transforming society" (ibid., p. 12). Among other key competencies, ESD aims to strengthen reflexivity and critical systemic thinking, participation and cooperation, as well as a sense of responsibility, enabling individual and collaborative action for sustainability [7-9].

Throughout the UN Decade for ESD from 2005 to 2014 [10] and the subsequent Global Action Programme (GAP, 2015-2019) [6], ESD received widespread attention in learning processes as well as 
educational and sustainability-related science $[7,11,12]$ and policy $[13,14]$. Integrated as an explicit target within the Sustainable Development Goals (SDG 4.7), the implementation of ESD in national educational systems has become a high-level political task [15,16], effectively contributing to sustainable development on several levels [17]. To foster the process of ESD-implementation in Germany, a participatory multiactor policy process including a National Platform as well as Expert Forums and Partner Networks on all education areas was designed [18]. As the German contribution to the GAP on ESD, the National Platform adopted a National Action Plan in 2017, specifying goals and self-given commitments for all education areas [19]. One of its main overarching objectives is the structural implementation of ESD in formal documents (e.g., curricula, laws, examination regulations, or vocational training programs) [19].

As part of a multimethod approach to monitoring the ESD implementation in Germany, this study assesses the status and progress of the formal integration of ESD in such documents at the end of the GAP. Within the following two sections, key characteristics of the monitoring approach as well as an introduction into the research design and the underlying baseline assessment are presented.

\subsection{Monitoring ESD-Tracing Its Implementation}

Encompassing all system layers from (inter)national governance for ESD across state politics, regional educational landscapes, specific institutions and teachers, down to individual moments of transformative learning, the implementation of ESD is a complex endeavor. As such, its effective diffusion requires both system- and process-specific knowledge available to all stakeholders involved. Attempts to analyze or systematically monitor the related educational processes and policy efforts have thus become a fundamental part of the (inter)national progress of ESD implementation $[13,14,17,20,21]$. However, the evidence created not seldomly lacks important preconditions for an independent and comprehensive, yet differentiated and supportive, assessment of ESD implementation.

Concerning the criterion of independence, particularly (self-)reporting by countries or organizations has, given its political nature, sometimes remained uncritical in focusing on achievements and success stories instead of creating transparency regarding failures, problems, and effective ways for improvement [22]. Regarding the encompassing and long-term nature of the approach, the majority of current international monitoring projects evaluate ESD in specific educational contexts such as within institutions or programs [17], certain subjects (e.g., [23-25]) or only consider specific educational sectors (e.g., [26,27]). These institution-, field-, or subject-specific insights are decisive for a detailed and differentiated understanding of aspects of the education process. However, systematic, cross-cutting, and ideally cross-temporal assessment of ESD throughout educational areas (horizontal) and covering different levels of the governance of ESD (vertical) appear to be of high strategic value for policy development targeting holistic ESD implementation. Such monitoring becomes supportive by also aligning its design towards applicability to relevant stakeholder groups and their needs.

The purpose and design of the project German Monitoring of the GAP ESD at the Institut Futur, Freie Universität Berlin, are aligned towards these criteria in order to significantly contribute to the systematic production of scientific knowledge on the quality and quantity of ESD within the German education system and on ways to effectively foster its implementation. The research design of the project encompasses several methodical approaches such as quantitative, qualitative, and mixed-method studies. A central element is large-scale, indicator-based, longitudinal document analysis on the formal anchoring of ESD within core documents of the German education system.

\subsection{Longitudinal Document Analysis}

Conceptually, formal documents, a central steering tool within educational governance, can be understood as important connectors between providers and recipients of education, holding great potential for action [28]. As such, the integration of ESD within particularly governance- and curriculum-related documents is of high importance for the diffusion of ESD through (i) provision of formal and normative guidance and (ii) promotion of conceptual frameworks that offer further 
didactic knowledge for its practical implementation. Thus, even though a considerable gap between rhetoric and action is to be assumed [29], structural implementation of ESD within key documents nonetheless serves as crucial strategic leverage for transferring and upscaling ESD into practice. At the same time, the available international literature also points to the inherent challenges of such a structural integration within all areas of education [27,30-33].

To gain an initial overview of the status quo of formal ESD implementation in Germany, in 2017, the monitoring team conducted a baseline document analysis with a key focus on documents published between 2012 and 2017 [34,35]. While the results indicated that the goal of broad ESD anchoring in formal documents had not been achieved at this point, considerable differences were identified among federal states and areas of education. Moreover, ESD and related concepts were found more frequently in more recent documents, indicating a positive trend of ESD implementation. Comparing the frequency with which ESD was mentioned in documents with other related educational concepts such as Environmental Education or Global Citizenship Education, the study also pointed to an increasingly prominent role of ESD within the education system of Germany.

This study continues the process of monitoring the formal implementation of ESD within the four formal areas of the German education system (early childhood education, school education, higher education, and vocational education and training) by replicating and refining the first analysis at the end of the GAP. While the baseline analysis was conducted shortly after the National Action Plan on ESD, Germany's contribution to the GAP, and had been published in 2017, this present assessment provides valuable insights on the status of ESD anchorage after the GAP. As a result of this longitudinal design, the study also serves as an evidence base for the official German ESD implementation structures, including the abovementioned National Platform on ESD, on how to effectively foster German ESD implementation at the level of documents throughout the new UNESCO program "ESD for 2030". Moreover, the methodological approach may serve as a practical example to other (inter)national monitoring projects aimed at a systematic and longitudinal assessment of the formal implementation of ESD.

In the following chapter (Section 2), the methodological approach to conducting the document analysis is introduced. Thereafter (Section 3), the results for each of the four formal areas of education are presented. The article concludes with a summarizing and contextualizing discussion (Section 4).

\section{Materials and Methods}

To identify the status and progress of ESD implementation in central documents of the German education system, the monitoring project utilized an indicator-based lexical content analysis [36]. The set of nationally specific indicators designed for the first document analysis in 2017 (for details, see [34] (pp. 3-6) and [35] (pp. 25-34)) was derived from literature on both education monitoring in general $[37,38]$ and the national and international implementation of ESD (inter alia [20,39-41]). The first study from 2017 included a total of 2795 documents from early childhood education, school education, higher education, and vocational education and training.

For this study (10/2019), the focus was placed on documents which:

(i) had been revised since the first study (03/2017; [34]);

(ii) are relevant to the implementation of the National Action Plan on ESD [19]; and

(iii) are of central strategic importance for the further implementation of ESD in the different states and areas of education.

The inclusion of new types of documents for (ii) and (iii) was based on a trans disciplinary process considering feedback from experts on ESD who are members of the national GAP ESD implementation structure, as well as insights from interviews with experts in the four areas of education [42]. For an overview of all types of documents included in the study, see Table 1. 
Table 1. Types of documents included in the present study according to area of education. In brackets: Number of new documents.

\begin{tabular}{|c|c|c|c|c|}
\hline Categories of Documents & $\begin{array}{l}\text { Early Childhood Education } \\
\qquad(n=182)\end{array}$ & $\begin{array}{l}\text { School Education } \\
(n=780)\end{array}$ & $\begin{array}{l}\text { Vocational Education and Training } \\
\qquad(n=321)\end{array}$ & $\begin{array}{l}\text { Higher Education } \\
\quad(n=430)\end{array}$ \\
\hline Laws/education acts & Federal and state laws (67) & Laws of all 16 states (43) & Federal and state laws (11) & Laws of all 16 states (39) \\
\hline Resolutions/recommendations & $\begin{array}{l}\text { Resolutions of the Standing } \\
\text { Conference of the Ministers of Youth } \\
\text { and Family Affairs (JFMK) (50) }\end{array}$ & $\begin{array}{l}\text { Resolutions of the Standing } \\
\text { Conference of the Ministers of } \\
\text { Education and Cultural Affairs } \\
\text { (KMK) (19) }\end{array}$ & $\begin{array}{l}\text { Board resolutions and expert studies of } \\
\text { the Federal Institute for Vocational } \\
\text { Education and Training (BIBB) and the } \\
\text { Committee on Vocational Education } \\
\text { within the KMK (33) }\end{array}$ & $\begin{array}{l}\text { Positions, recommendations, and } \\
\text { resolutions of the German and Regional } \\
\text { Rectors' Conferences (HRK/LRK) (51) }\end{array}$ \\
\hline $\begin{array}{l}\text { Curricula/education plans, etc., } \\
\text { for learners }\end{array}$ & Education plans of all 16 states (4) & $\begin{array}{l}\text { School curricula of all } 16 \text { states }{ }^{1} \\
\text { for } 9 \text { selected subjects }(316)\end{array}$ & $\begin{array}{l}\text { Training regulations for } 14 \text { selected } \\
\text { professions and new or restructured } \\
\text { training regulations for all professions } \\
\text { (2015-2019) (88) }\end{array}$ & $\begin{array}{c}\text { Course handbooks of } 3 \text { subjects from } 15 \\
\text { selected universities }{ }^{2}(205)\end{array}$ \\
\hline $\begin{array}{l}\text { Training regulations for } \\
\text { educators }\end{array}$ & $\begin{array}{l}\text { Curricula of courses in early } \\
\text { childhood education in all states (44) }\end{array}$ & $\begin{array}{c}\text { Course handbooks and } \\
\text { study/examination regulations } \\
\text { for teacher training in five } \\
\text { selected states (402) }\end{array}$ & $\begin{array}{l}\text { Course handbooks and } \\
\text { study/examination regulations for teacher } \\
\text { training in five selected states (183) }\end{array}$ & - \\
\hline $\begin{array}{l}\text { Other relevant types of } \\
\text { documents }\end{array}$ & $\begin{array}{c}\text { Mission statements and } \\
\text { quality-development-related } \\
\text { documents of federal associations (17) }\end{array}$ & - & $\begin{array}{l}\text { National Reports on Vocational } \\
\text { Education and Training (6) }\end{array}$ & $\begin{array}{l}\text { Target agreements between states and } \\
\text { institutions of higher education (81); } \\
\text { University Development Plans (as } \\
\text { available) of all states (11); Mission } \\
\text { statements (13), sustainability reports (12) } \\
\text { and internationalization strategies (18) of } \\
15 \text { selected institutions }\end{array}$ \\
\hline \multicolumn{5}{|c|}{$\begin{array}{l}{ }^{1} \text { A selection of nine subjects (German, English, Economics, Politics, Ethics/Philosophy, Geography, Chemistry, Biology, Information Technology) and two grades (4; } 9 \text { ) in primary and } \\
\text { secondary schools was applied (for details see [43]). }{ }^{2} \text { Mechanical Engineering (technical position on sustainability), Business Administration (highest number of graduates), and Biology } \\
\text { (sustainability-related subject) were included. }{ }^{3} \text { The selection of higher education institutions was based on the numbers of teacher training graduates (2013/14), number of all graduates } \\
\text { (for universities in 2013/14, for other higher education institutions in 2015/16), research strength (measured by third-party funding), and best-practice function in terms of sustainability (for } \\
\text { details, see p. } 213 \text { [44]). }\end{array}$} \\
\hline
\end{tabular}


The transdisciplinary process involving feedback from experts resulted in the inclusion of new types of documents compared to the first analysis in 2017 (e.g., internationalization strategies in higher education, new or restructured training regulations in vocational education from 2015 to 2019). For the present study, a total of 1713 new documents were collected at two points in time (July 2018; October 2019) and analyzed together. Within the selection criteria defined for each type of documents (Table 1), all available documents were assessed. One crucial reason for the complexity of demarcating, compiling, and analyzing this cross-sectional dataset is, besides coverage of all four formal areas, the structure of the federal education system in Germany, where the 16 state jurisdictions have vast degrees of autonomy concerning educational issues, framed by few national laws. An exception is vocational education and training, which has a more centralized structure regarding training regulations.

After collection, it was ensured that all documents are readable in MAXQDA 2018.2, followed by a lexical analysis based on a list of key words. For the latter, the conceptual list of keywords used in the first document analysis [34] was further developed to represent a comprehensive spectrum of ESD-related concepts and perspectives (see Table 2). While the focus on concepts was deliberately chosen to implicitly account for didactic and organizational characteristics not included in thematic keywords, the proposed list may be considered part of a wider discourse on the meaning and scope of ESD (for an alternative list, see [45]). Although a general focus was placed on concepts within all educational areas, an additional thematic search was applied within vocational education and training to represent its strong practical focus within this study, including the keywords 'climate,' 'environment,' 'responsibility,' and 'combinations' of two or more dimensions of sustainability (social, ecological, and economic).

Table 2. Keywords used for the lexical analysis (translated from German for this publication; alternative suffixes as well as singular and plural forms were included in the search).

\begin{tabular}{|c|c|}
\hline \multicolumn{2}{|c|}{ Conceptual List of Keywords } \\
\hline Education for Sustainable Development & Sustainability/Sustainable Development \\
\hline $\begin{array}{ll}\text { - } & \text { Education for Sustainable Development } \\
\text { - } & \text { Education as Sustainable Development } \\
\text { - } & \text { ESD }\end{array}$ & $\begin{array}{ll}\text { - } & \text { Sustainability } \\
\text { - } & \text { Sustainable Development } \\
\text { - } & \text { Sustain (in German and English) }\end{array}$ \\
\hline Educational concepts related to ESD & Perspectives on and from ESD \\
\hline $\begin{array}{ll}\text { - } & \text { Shaping competency } \\
\text { - } & \text { (Gestaltungskompetenz, see [7]) } \\
\text { - } & \text { Global citizenship education } \\
- & \text { Climate education* } \\
- & \text { Global learning } \\
- & \text { Learning in global contexts } \\
- & \text { Development policy education } \\
- & \text { Environmental education/pedagogy } \\
- & \text { Nature education/pedagogy } \\
- & \text { Ecological education }\end{array}$ & $\begin{array}{ll}\text { - } & \text { Global Action Programme* } \\
\text { - } & \text { Whole Institution Approach (as noun and adjective) } \\
\text { - } & \text { Whole School Approach* } \\
\text { - } & \text { Sustainable Development Goals/SDG/Agenda 2030* } \\
\text { - } & \text { Intergenerational/future generations* } \\
\text { - } & \text { Global development* } \\
\text { - } & \text { Planetary boundaries* }\end{array}$ \\
\hline
\end{tabular}

New keywords which were not part of the first document analysis [34,35] are indicated by *.

To avoid incorrect coding of the text passages that contained keywords from the list, all matches of the lexical search were verified by manually assigning them to the codes in MAXQDA that conform with the list of key words. Where uncertainty prevailed (e.g., use of the German 'sustainable' ("nachhaltig") in the sense of durable, not sustainable), a peer debriefing $[46,47]$ was held to decide whether these text passages were to be coded or not. Due to the changes in the list of keywords, all data from the first analysis $[34,35]$ were lexically searched again with the new keywords. All codings were quantitatively 
counted and qualitatively contextualized. Considering that defining a "good status" of ESD integration is a democratic task, the results were interpreted in relation to the goals set during the GAP, e.g., within the National Action Plan [19], priorities identified by experts within the field [42], as well as in the light of previous results from the first document analysis [34].

\section{Results}

Throughout the GAP, the educational concept of ESD has increasingly been implemented within the formal structures of the German education system. However, this progress varies widely between (i) the 16 federal states, which are primarily responsible for legislating and organizing education in Germany, (ii) the four separate formal areas of education, and (iii) the different types of documents. This chapter presents the key findings of the document analysis within the four formal areas of education for each type of document with a particular focus on longitudinal developments and strategic perspectives to further strengthen the structural implementation of ESD in Germany.

\subsection{Early Childhood Education}

As a first institutionalized setting for learning outside the family, early childhood education plays an important role in shaping people's abilities to co-create a sustainable future $[33,48]$. With its value-based and co-constructivist approach, ESD has the potential to contribute to creating holistic learning environments.

Within what we summarize as political framework documents concerning early childhood education (laws, resolutions of responsible political committees), the educational concept is only marginally anchored at the end of the GAP. While ESD is not referred to in any related state or federal law, one state (Bavaria) mentions an associated concept (environmental education) within their regulatory documents. A positive trend since the first study in 2017, however [34], is identifiable regarding the positioning of the JFMK (Standing Conference of the Ministers of Youth and Family Affairs). It formally recognized the National Action Plan on ESD in 2018 and decided to accompany its implementation through the working group for youth and family affairs (AFJF). It is important to highlight this development, as recognition of the National Action Plan on ESD within positionings of the JFMK may provide orientation based on the goals and commitments described within the plan. Therefore, it could provide significant visibility and legitimacy for ESD implementation within early childhood education.

The education plans of the federal states have gained importance in recent years as early childhood education is increasingly approached as a formalized educational field [42,49]. Since the first in-depth analysis of all education plans in 2017 [34,50], four of the 16 states have either revised their plans or made them publicly available (Bremen, Lower Saxony, Rhineland-Palatinate, Saarland). In congruence with the results of the first study [34], the new data confirm the ongoing trend for ESD to be structurally implemented in the education plans, with three of the four new documents incorporating the educational concept. In total, nine out of the 16 states currently denominate ESD within their education plans. Particularly the states of Saarland (2018) and Rhineland-Palatinate (2014, publicly available since 2018) have since integrated ESD as a core concept within their revised plans. For example, the latter explicitly framed the educational concept as a cross-sectional task in a dedicated chapter underscoring the importance of competencies such as anticipatory and interdisciplinary thinking, empathy, solidarity, and sustainable action in the context of sustainable development [51]. Of the older documents analyzed within the first study [34], the city-states Berlin and Hamburg also stood out with designated chapters on ESD. Among the nine states that had integrated ESD within their education plans until 2019, strong differences remain between those that comprehensively integrated the educational concept as a cross-sectional task and others that highlighted its importance only within specific contexts such as in STEM (science, technology, engineering, and mathematics) education (see also [52]). 
With regard to the curricula of courses in early childhood education (nonuniversity level, often as part of vocational education and training), the first analysis in 2017 revealed a clear uptake of ESD-related concepts that again varied greatly between the federal states [34]. For this analysis, the training courses included in the first analysis (for details, see [50]) were checked for revised documents. Of the 44 revisions from 13 federal states, ten documents from three states contained considerable new evidence of ESD or associated concepts. Particularly the state of Rhineland-Palatine systematically integrated ESD within the curricula for vocational training schools (2019), referring to it as an interdisciplinary task aiming to develop shaping competency [7], and to enable individuals to get involved in sustainable development individually and cooperatively. The findings indicate an overall continuation of the previously described increase in ESD implementation, especially in the light of long time periods between revisions to these types of documents. As highlighted via the example of Rhineland-Palatine, an important factor influencing training regulations in Germany and also potentially catalyzing the diffusion of ESD within early childhood education could be integration of the educational concept in the process of standardization in vocational education and training.

In addition to the longitudinal analysis of the aforementioned documents, this study also exploratorily considered mission statements and documents related to quality development of four large federal associations involved in the provision of early childhood education: Diakonie, AWO (Arbeiterwohlfahrt), KTK (Verband Katholischer Tageseinrichtungen für Kinder), DRK (Deutsches Rotes Kreuz [German Red Cross]). No anchoring of ESD or related educational concepts was found, but two of the associations (AWO and Diakonie) referred to organizational sustainability and sustainable development within the quality-development-related documents analyzed. While these results are only tentative in the sense that the data were strongly heterogeneous and only four of the numerous associations responsible for early childhood education were considered, they do point to the importance of structurally including these associations as important stakeholders in the process of ESD implementation in early childhood education.

\subsection{School Education}

School education is the longest formal educatory setting for most individuals. As such, it has a pronounced responsibility to foster competencies, knowledge, and values which enable people to become agents of change with the ability to co-create sustainable societies.

At the time of this study, the educational concept ESD had been formally integrated into the education acts of four out of Germany's 16 federal states. While ESD is framed as a special interdisciplinary task within the education acts of Berlin, Hessen, and Mecklenburg-Vorpommern, the state of Lower Saxony anchored ESD within the underlying goals and objectives of education in analogous and equally binding document types ("circulars") on work within primary and secondary schools. Additionally, three states (Bavaria, Lower Saxony, Saxony) also directly refer to the concepts of sustainability/sustainable development as a key objective of school education. In terms of related educational concepts, the education acts explicitly refer to environmental education (Berlin, Brandenburg, Hamburg, Hessen, Lower Saxony, Saarland), learning in global contexts (Berlin), ecological education (Berlin), and global learning (Lower Saxony).

As a result of the far-reaching responsibility the individual federal states have for education, resolutions and recommendations of the Standing Conference of the Ministers of Education and Cultural Affairs (KMK) are particularly influential in shaping the organization and development of school education in Germany. The conference, in which each federal state is represented, provides common orientation within the area of education and publishes recommendations for all states. Against the backdrop of this important role, as well as the declared goal to support and upscale ESD [53], only very few references to ESD and related concepts were found in the KMK publications from 2011 to 2016 during the first analysis [34,43]. The results of the present analysis encompassing documents from 2017 to 2019 suggest that ESD continues to be integrated sporadically, with seven of the 19 resolutions referring to ESD at least once. While six of those seven documents are not 
explicitly devoted to the subject, one document from 2017 is a request to all 16 federal states to self-report on the status and perspectives of ESD implementation. Even though it does not constitute a resolution or recommendation in itself, the document summarizes the self-reports of the 16 states regarding ESD-related governance, uptake in curricula, teacher training, cooperation between relevant educational actors, needs for additional action, and plans for future efforts promoting ESD [54].

As a key type of document for the diffusion of ESD within SE, the school curricula of all 16 federal states for nine different subjects in grade four (primary education) and nine (secondary education in all types of schools) were considered. Within these curricular documents, 15 out of 16 federal states mentioned ESD at least once. The sixteenth, Hessen, revised its education act in 2018, positioning ESD at the core of the state's objectives for education, indicating imminent revision of the curricula in realization of the education act. Although all states do refer to ESD and related concepts, quantitatively and qualitatively, strong differences are identifiable. While some have already set ESD as a central guiding principle across all disciplines (e.g., Baden-Wuerttemberg and Saxony), including comprehensive organizational and methodological concretization, others only refer to ESD and related concepts within specific subjects with a high affinity to sustainability (e.g., Geography). Overall, the results indicate a clear trend of ESD implementation within school curricula in Germany, recently revised documents showing a generally high quantitative abundance and qualitative integration of ESD (e.g., ESD in new curricula of Baden-Wuerttemberg (2017), Berlin/Brandenburg (2017), Saxony (2019), North Rhine-Westphalia (2019), and Mecklenburg-Vorpommern (2019)).

To transfer ESD from education acts, political documents, and curricula into practice, it is essential to integrate the educational concept within teacher education. This study analyzed teacher training course handbooks and course/examination regulations from 15 higher education institutions with the largest number of teaching graduates from five selected federal states (Baden-Wuerttemberg, Berlin, Lower Saxony, North Rhine-Westphalia, Saxony; three institutions each). The data were then analyzed and compared with the previous results from 2017 [34,43]. Here, a high discrepancy is to be noted between the abovementioned increase in structural implementation of ESD in curricula and its integration into teacher training. While no or very few references to ESD and related concepts were found within the documents from Lower Saxony, North Rhine-Westphalia, and Saxony, some subject-specific matches were found for Berlin and Baden-Wuerttemberg. Additionally, a slight trend towards integrating sustainability/sustainable development in the teacher training course handbooks could be identified. This result points to a key structural hole within the implementation efforts, given that all states are already explicitly mentioning ESD within their laws and/or curricula to some extent.

\subsection{Vocational Education and Training}

As part of the modernization process within vocational education and training in Germany [55], ESD can directly contribute to the creation of learning environments in which people work together to co-design sustainable economies that work for all. Contextualizing the results, it is important to keep in mind that vocational education in Germany is characterized by a strong practical orientation and a dual structure of business-integrated training in collaboration with vocational schools [56]. Also, while the political framework for the vocational schools is set by the federal states, business-integrated vocational training is structured by the national government.

With regard to federal and state laws, the analysis focused on the state-specific education acts for schools and the two major federal regulations on vocational education. The state laws for vocational schools are part of the general education acts, and, therefore, the results are the same as those described in Section 3.2. (p. 8), with the exception of primary- and secondary-school-specific circulars in Lower Saxony. The federal laws (Berufs-bildungs-gesetz [Vocational Training Act], Handwerks-ordnung [Crafts Code]) did not contain references to ESD and related concepts.

Within vocational education and training in Germany, the Federal Institute for Vocational Education and Training (BIBB) acts as a government-funded scientific body that supports the development of the educational field. As it is divided into two separate parts, the board and the 
institute, documents from both were considered. The board resolutions of the BIBB are of key strategic importance for the diffusion of innovations within the education system. As the majority of references to thematic keywords, particularly within training regulations, refer to a board resolution on environmental protection from 1991, the projected update of this resolution with regard to sustainability [19] can be regarded as important leverage for ESD implementation. However, for 2011-2019, none of the board resolutions mentioned sustainability, ESD, or related concepts. Similarly, the analyzed expert studies by the BIBB institute on vocational education policy, science, and practice (2005-2018) did not refer to sustainability, ESD, or related concepts. In the light of these results, it is important to point to the BIBB's important role in shaping the programmatic discourse on ESD within the educational field, inter alia by administrating the funding of ESD model projects and preparing parts of the national report on vocational education and training. Against this backdrop, the minor focus on ESD within the BIBB's research and the resolutions of its board seems remarkable.

In the National Reports on Vocational Education and Training (2011-2019), ESD and sustainability are referred to regularly. While the majority of explicit denominations of ESD were found in recurring descriptions of two large federal/EU funding programs aimed at the structural integration of ESD within the area of education, the report from 2018 directly addresses the obligation of the Ministry of Education and Research and relevant stakeholders to implement the National Action Plan on ESD and its objectives [57] (p. 73). Within the additional data report of the same year (provided by the BIBB), this progress is substantiated with explicit steps forward, e.g., plans to update the aforementioned BIBB resolution on the integration of environmental protection within training regulations [58] (p. 81). The analysis of the national reports indicates a tendency for ESD to be given a more central position within the programmatic discourse on the future of vocational education. At the same time, the reports do not demonstrate that much progress has been made towards structurally implementing ESD as a transformative educational concept in a comprehensive and cross-sectional manner.

Another important factor for political leverage for accelerating ESD lies within the vocational-education-specific resolutions of the KMK. Of the 19 relevant new documents (2017-2019), two referred to ESD (training of educators within early childhood education (2017; [59]); framework for the creation of curricula for training regulations (2018; [60]). While particularly the latter is to be valued as a significant structural development, the KMK has still released only very few job-specific concretizations of ESD or sustainability (see also [61,62]) in recent years, just as no explicit resolutions were on the National Action Plan on ESD or the GAP. Also, while the analysis of thematic references (exclusively conducted in vocational education and training, see methods) shows a relatively high number of references to environmental damage and protection, no positions were found on climate, climate change, or climate protection, indicating untapped potential with regard to climate education.

The training regulations for apprenticeships of a given discipline are effective in all the German federal states. As such, they are an important indicator for the structural implementation of ESD and related concepts. In 2017 [34], the training regulations of 14 of the 326 officially recognized professions in Germany [63] were analyzed. While none of the documents included references to ESD or related educational concepts, four referred to sustainability as part of the training regulations. For this study in 2019, the 14 professions included in the first study were assessed again. Additionally, all training regulations from all professions which had been changed or newly invented since 2015 were considered (an extra 50 professions). Overall, training regulations of 64 professions (or groups of professions with shared training regulations) were included. Of these, ten contained references to sustainability and none to ESD or other related educational concepts. While a slight recent trend towards integration of sustainability within training regulations is recognizable, the results indicate a need for vast additional efforts to structurally implement ESD/sustainability cross-disciplinarily. With regard to environmental protection, such cross-disciplinary integration has indeed taken place, initiated through the aforementioned BIBB board resolution: all 64 professions included environmental protection as a focus. Furthermore, analysis of combinations of the keywords "social," "ecological," 
and "economic" shows that no training regulation combined all three aspects and, when two of the dimensions were mentioned, 336 of the 337 text passages included the economic focus as one of the two. This highlights the need for further efforts to include all dimensions of sustainability.

As the structure of teacher training within vocational education and training varies considerably between states and professions, a sample of course handbooks and study/examination regulations from 17 higher education institutions (Karlsruhe, Mannheim, Stuttgart, Göttingen, Hannover, Lüneburg, Osnabrück, Dortmund, Köln, University of Applied Sciences Münster and University of Münster, Erfurt, Jena, Ilmenau, Humboldt Universität Berlin, Freie Universität Berlin, Technische Universität Berlin) in five states (Baden-Wuerttemberg, Berlin, Lower Saxony, North Rhine-Westphalia, Thuringia) were analyzed in 2017 and 2019. A focus was placed on the 14 selected professions which were analyzed in both studies as well as on Philosophy, Social Science, and Economics courses. Against the backdrop of highly heterogeneous data, the study from 2017 suggested a very low anchoring of ESD and sustainability within these documents. This result and its limitations (heterogeneity) were generally supported by this replication. Although individual modules with a focus on sustainability within several courses were added and two of the 17 higher education institutions explicitly referred to ESD in their module guidebooks, no comprehensive pattern of ESD implementation could be identified.

\subsection{Higher Education}

Institutions of higher education are vital actors within a societal transformation towards sustainability: in their research, education, and operations, they have a special responsibility to be, as they call themselves, the "future labs of society" [64]. At the same time, the system of higher education is characterized by a controversial tension between the constitutionally granted autonomy of institutions and the societal or political attempts to influence their directions. Hence, this analysis addresses both political and institution-specific documents.

In the realm of political documents, higher-education-specific laws of the $\mathbf{1 6}$ federal states set the binding regulatory framework for the educational field. While ESD is currently not integrated in any of the documents, sustainability/sustainable development is being addressed in six state laws as an important objective and foundation of higher education. While Thuringia and Rhineland-Palatinate added this focus to their laws in 2018, the state of North Rhine-Westphalia deleted references to sustainability within their revised law (2019). While a slight positive trend concerning sustainability can be noted, comprehensive implementation of ESD is still not stipulated by the laws of the federal states.

Constituting a relatively new steering instrument for states within the educational area, not all states currently have statewide University Development Plans. At the time of the first Desk Research in 2017, of the nine states with University Development Plans, only the state of North Rhine-Westphalia had explicitly integrated ESD, six other states referring to sustainability or sustainable development $[34,44]$. For this analysis, all revisions and new development plans published since 2017 were collected. At the time of this study, ten states had published relevant documents with Thuringia being the only addition to the prior group of nine states. Of the five plans that had been revised since the first study, two (Bavaria and Bremen) point to the importance of ESD and also mention the National Action Plan and its implementation. Additionally, all of the revised plans include the concept of sustainability as a core principle or fundamental objective of higher education institutions (Bavaria, Bremen, Lower Saxony, Saxony, Thuringia). The results thus not only indicate a clear trend towards (E)SD implementation within University Development Plans, but also show an effect of the National Action Plan on ESD.

Highlighted by experts in the field as a key leverage point for implementing ESD in Higher Education, target agreements between the federal states and institutions of higher education are considered to be strategic steering instruments $[42,65]$. While the first analysis showed only sporadic references to ESD within these documents [34,44], a strong trend of ESD implementation was evident during the period of this study. Particularly, the new target agreements in Bavaria (5 out of 25), Berlin (11 out of 11), Brandenburg (8 out of 8), Lower Saxony (14 out of 20), and Schleswig-Holstein (1 out of 1) explicitly integrate ESD as a substantial part of higher education. Additionally, all universities in 
Hamburg are, by means of their target agreements, orienting their activities around the principles of sustainable development. As a good example of comprehensive structural integration of ESD within target agreements, Brandenburg stated that all aspects of higher education (research, teaching, transfer, governance) of all universities need to be oriented towards sustainability, inter alia specified by an integration of ESD in mission statements, curricula, and coaching for teachers (e.g., [66]). Overall, the revisions of target agreements indicate a strong trend towards ESD integration within these key strategic documents.

While considerable momentum can be observed within the political and mostly federal state-controlled laws, plans, and agreements, the analyzed documents that are specific to and written by higher education institutions prove to be less ambitious at present.

With regard to positions, recommendations, and resolutions of the German and Regional Rectors' Conferences (HRK/LRK), initial analysis of documents between 2011 and 2016 showed very few references to sustainability and no references to ESD [34,44]. Of the 19 documents issued by the HRK and 32 documents issued by the regional LRKs between 2017 and 2019, only one HRK resolution explicitly refers to ESD. Within the recommendation "For a Culture of Sustainability" (translated from the German; [64]), the HRK points to the important role of higher education institutions in the transformation towards sustainability. At the same time, the Rectors' Conference takes a particular stance for scientific freedom, autonomy, and more financial support instead of stricter guidelines or compulsory reporting [64] (pp. 5-6).

Aiming to shed light on the implementation of ESD within higher education institutions, mission statements, sustainability reports, internationalization strategies, and study programs of 15 selected institutions were analyzed. Given that only 15 out of over 400 institutions in Germany were included, the results serve as an initial insight, not as a detailed analysis. Also, as three of the 15 institutions were explicitly sampled as best-practice cases for sustainability (the Universities of Lüneburg and Tübingen, Eberswalde University for Sustainable Development (HNEE)), the results for these institutions cannot be interpreted as reflecting the overall integration of ESD or sustainability within higher education institutions (see [44] for details on the selection process).

Regarding the mission statements, no changes were identified since the first analysis [34,44]. Still, six out of the 15 institutions, including all three best-practice cases, refer to sustainability or sustainable development within research, education, and operation, while ESD is not explicitly mentioned. Reports on sustainability or directly related topics were available from seven of the 15 institutions included, four of the reports from the first analysis [34,44] having been revised and one new report having been issued. Five of the seven available reports (all three best-practice institutions, the University of Hamburg, and TU Dresden) referred explicitly to ESD. While the results indicate only a slow trend towards further integration of ESD and sustainability within reporting, this needs to be interpreted against the backdrop of the short time period between the two assessments and the long process for establishing high-quality sustainability reports.

In the light of the manifold and complex interactions between internationalization and sustainability, this study also assessed the integration of ESD and related concepts in internationalization strategies. The documents are very heterogeneous and were available for eight out of the 15 institutions. Of these, three documents of the HNEE, the University of Hamburg, and TU Dresden referred to Sustainable Development as an essential part of internationalization; none referred to ESD as an educational concept.

Within the study programs of the three subjects analyzed (Biology, Business Administration, and Mechanical Engineering), the concepts of sustainability and sustainable development appeared to be integrated with widely varying degrees of comprehensiveness in 2017 [34,44]. However, references to ESD and related educational concepts were rare. This had not changed considerably by 2019. While a slight trend towards additional thematic references to sustainability and sustainable development could be noted in the new documents (2017-2019), ESD or related concepts were not included in any of the revisions. 


\section{Discussion}

The results of this document analysis may serve as a valuable foundation for evidence-based policy recommendations within ESD governance, constituting a benchmark for the future process of systematically anchoring ESD within the German education system. While in a narrower sense, the study is an independent monitoring of goals set during the UNESCO GAP on ESD and the German National Action Plan, more broadly, it also offers a methodological framework for further national and international analyses of the structural implementation of ESD within education systems. Within this discussion, the status and progress of ESD implementation in the German education system is briefly summarized and contextualized for all sectors of education. Subsequently, some methodological challenges of conducting large-scale document analyses are discussed before ending with an outlook on the broader context of monitoring ESD.

\subsection{Status and Progress of ESD Implementation in the German Education System}

The progress of implementing ESD within the key formal documents of the German education system gained momentum over the duration of the GAP. At the same time, large discrepancies remain between the areas of education, different types of documents, federal states, and with regard to the quality of the contextualization of ESD and related concepts. As ESD continues to be more prevalent in more recent documents, indicating an ongoing implementation process, this study shows a significant increase in the uptake of ESD within key strategic types of documents that were also addressed within the National Action Plan on ESD [19] (e.g., target agreements in higher education, curricula in school education). In contrast, the diffusion of ESD within documents on training multipliers (kindergarten and school teachers, vocational education trainers) remains a critical issue that requires further attention throughout the UNESCO follow-up program "ESD for 2030".

In the following, the results for each educational area are briefly summarized and contextualized.

Within early childhood education, the implementation process continued throughout the GAP with considerable emphasis on the anchoring of ESD and related concepts in the educational plans of the federal states and within training courses for educators in early childhood education. Such progress within curricula was also reported from other countries [67], highlighting the importance of further strengthening the depth and quality of anchoring in further revisions. Also, particularly regarding training regulations, the international trend towards academization in early childhood education potentially opens further doors for the implementation of ESD, especially as an elaborate understanding of sustainable development and the associated pedagogical practices can be fostered in higher education [68]. While only marginal integration of ESD can currently be observed within the related education acts, particularly the JFMK seems to be taking on a stronger position within the process. Given the orientational role of the JFMK, this may be cautiously interpreted as a sign of further active efforts on the part of the federal states to foster ESD implementation in early childhood education.

In school education, ESD is increasingly integrated within the curricula of the federal states. At the same time, considerable differences regarding the conceptual depth and interdisciplinary character remain, indicating further potential for implementation. While a number of states have taken up ESD as a cross-disciplinary perspective and central strategic guideline (e.g., Baden-Wuerttemberg, Saxony), others refer to ESD and related concepts only within specific subjects, particularly those that have an inherent affinity to sustainability. This mirrors, as an example of another federal education system, recent findings from Canada, where similar heterogeneities among provinces became apparent within documents related to governance and curricula of ESD [27], and is in line with the analysis of different approaches to anchoring ESD in Sweden and Japan [31]. A heterogeneous, but positive trend is also recognizable within the state's education acts. Contrary to the developments within curricula and laws, but in alignment with other international findings [69], strong additional efforts are required to structurally implement ESD within the documents of teacher training. It is crucial to address this discrepancy between an increased setting of ESD within curricula and laws and a lack of integration within teacher training during the further implementation of the educational concept. This could, for 
example, be effectively addressed by an updated and progressive resolution of the KMK on structural implementation of ESD within school education.

As part of a future-oriented approach to modernizing vocational education and training [70], ESD is increasingly being integrated as a way to further develop this stage of education. While the recent discourse on sustainability within vocational education and training manifests particularly within the national reports and funding programs, the implementation of ESD and sustainable development within political framework documents and training programs is, at present, slower and less dynamic. In alignment with international findings [30,71], additional efforts are also needed regarding the training of teachers with a focus on ESD. Given the effective implementation of environmental protection as a standard training element ("Standardberufsbildposition") in these structurally important documents, it seems sensible to pursue a timely revision of the BIBB board resolution with particular emphasis on sustainability and ESD. Besides a comprehensive focus on ESD as a guiding principle, such a resolution could also highlight the necessary competencies apprentices will require in a future-oriented job market [72-74].

Globally, there have been longstanding efforts and different waves to implement a focus on sustainability and ESD within higher education [32,75]. In Germany, the strong trend towards anchoring ESD within the target agreements between the federal states and the higher education institutions as well as in University Development Plans indicates an intensified state-initiated implementation process, which, however, has only partially found its way into the relevant state laws. The implementation trend is less pronounced within resolutions of the HRK/LRK (the self-governing bodies of higher education) and in the selected insight into documents of 15 higher education institutions. This indicates that impulses have mainly come from state initiatives rather than from the institutions themselves, pointing to the need for further strategies to strengthen sustainability/sustainable development within the higher education institutions [76]. Although efforts to report on sustainability are increasing [77], and the strong trend to use sustainable development for branding [78] may be interpreted as growing relevance of sustainability (not necessarily ESD) within the field, neither the publications of the self-governing bodies (HRK/LRK) nor the mission statements, internationalization strategies (see also [79]), or study programs show comprehensive, cross-institutional and cross-disciplinary ESD implementation at present.

\subsection{Monitoring ESD within Documents - Perspective and Outlook}

The independent research project to monitor ESD in Germany seeks to draw a bigger picture of the progress, stagnation, leverage points, and future needs for fostering ESD. This includes tracing the processes, inherent path dependencies, and potentials for improvement, both on the provisional and addressee side of education. In this way, the project may serve as an example to other independent, encompassing, and long-term ESD monitoring programs. As a central part of the approach, the present study provides insights into how to assess one of the fundamental coupling elements between ESD governance and its practical implementation: anchoring within documents.

To develop an encompassing yet differentiated perspective on the uptake of ESD and related concepts within specific education systems, we argue that it is important not only to use international indicators, but also to adapt and tailor approaches to specific contexts. Due to the size, heterogeneity, and complexity of the data, methodologically, the study proposes employing a combination of quantitative and qualitative assessments, including digital tools for data analysis such as MAXQDA paired with peer-coding of keywords and qualitative contextualization. While the process of conducting large-scale document analysis may initially seem dry and tedious, it does provide valuable insights for evidence-based policy recommendations.

For such an endeavor, it is equally important to point to a few unavoidable methodological challenges. Analyzing over 4500 documents, the stark heterogeneity and complexity of the dataset across time, federal states, and educational areas naturally limit internal comparability. Therefore, considering the different educational systems and layers of governance, no direct comparisons 
between the federal states or educational sectors could be derived from the data. While this needs to be considered, the diversity presented also mirrors and captures the real multifaceted nature of structurally implementing ESD within a complex education system. Moreover, the combination of quantitative assessment and qualitative contextualization points to a key question of conducting document analyses: what degree of ESD anchoring within a particular type of document (frequency and conceptual depth of text passages) is to be considered a "good status"? As answering this question is merely a democratic task, this present study focused its interpretations on goals that were set by actors themselves (e.g., within the National Action Plan, [19]) as well as on potentials and opportunities that were identified by experts within the field [42] or within the literature.

Regarding an overall outlook on the structural integration of ESD within the four formal areas of education in Germany, the study shows that the process of implementation gained momentum over the course of the GAP. At the same time, strong additional efforts continue to be required for comprehensive implementation of ESD as part of the UNESCO program "ESD for 2030". To achieve the purpose of ESD as explicated by UNESCO in 2014, "transforming society" [6] (p. 12), efforts should not focus solely on integrating ESD as a notion mentioned within documents, but serve as a conceptually substantiated and transformative agenda for the education system as a whole. This way, ESD may also serve as a way to reconsider the meaning of quality education in the 21st century-education that is able to prepare people across all disciplines and areas of education to co-create a sustainable future.

Author Contributions: Conceptualization, J.H., A.B., M.S.-B., and G.d.H.; data curation, J.H.; formal analysis, J.H., A.B., and M.S.-B.; investigation, J.H.; methodology, J.H., A.B., M.S.-B., and G.d.H.; writing-original draft, J.H.; writing-review and editing, J.H., A.B., M.S.-B., and G.d.H. All authors have read and agreed to the published version of the manuscript.

Funding: This research was funded by the Federal Ministry of Education and Research in Germany grant number WAPDH1820. We also acknowledge support from the German Research Foundation (DFG) and Leipzig University within the program of Open Access Publishing.

Acknowledgments: We would like to thank Janne von Seggern, Julius Grund, Theresa Grapentin-Rimek, Nadine Etzkorn, and Nicole Voss for their various contributions to this publication. Also, we thank the anonymous reviewers for their constructive feedback on the article.

Conflicts of Interest: The authors declare no conflict of interest.

\section{References}

1. Grin, J.; Rotmans, J.; Schot, J. Transitions to Sustainable Development: New Directions in the Study of Long Term Transformative Change, 1st ed.; Taylor \& Francis Ltd.: New York, NY, USA, 2010.

2. Steffen, W.; Rockström, J.; Richardson, K.; Lenton, T.M.; Folke, C.; Liverman, D.; Summerhayes, C.P.; Barnosky, A.D.; Cornell, S.E.; Crucifix, M.; et al. Trajectories of the Earth System in the Anthropocene. Proc. Natl. Acad. Sci. USA 2018, 115, 8252-8259. [CrossRef] [PubMed]

3. Raworth, K. A Safe and just Space for Humanity. Can We Live within the Doughnut; Oxfam: Oxford, UK, 2012.

4. Sterling, S. A Commentary on Education and Sustainable Development Goals. J. Educ. Sustain. Dev. 2016, 10, 208-213. [CrossRef]

5. Rockström, J. Bounding the Planetary Future: Why We Need a Great Transformation; Great Transition Initiative. 2015. Available online: https://greattransition.org/publication/bounding-the-planetary-futurewhy-we-need-a-great-transition (accessed on 25 April 2020).

6. UNESCO. UNESCO Roadmap for Implementing the Global Action Programme on Education for Sustainable Development; UNESCO: Paris, France, 2014.

7. De Haan, G. The development of ESD-related competencies in supportive institutional frameworks. Int. Rev. Educ. 2010, 56, 315-328. [CrossRef]

8. Vare, P.; Arro, G.; De Hamer, A.; Del Gobbo, G.; De Vries, G.; Farioli, F.; Kadji-Beltran, C.; Kangur, M.; Mayer, M.; Millican, R.; et al. Devising a Competence-Based Training Program for Educators of Sustainable Development: Lessons Learned. Sustainability 2019, 11, 1890. [CrossRef]

9. Wiek, A.; Withycombe, L.; Redman, C.L. Key competencies in sustainability: A reference framework for academic program development. Sustain. Sci. 2011, 6, 203-218. [CrossRef] 
10. UNESCO. Shaping the Future We Want. UN Decade of Education for Sustainable Development (2005-2014). Final Report. 2014. Available online: https://unesdoc.unesco.org/ark:/48223/pf0000230171 (accessed on 25 April 2020).

11. Grosseck, G.; Tîru, L.G.; Bran, R.A. Education for sustainable development: Evolution and perspectives: A bibliometric review of research, 1992-2018. Sustainability 2019, 11, 6136. [CrossRef]

12. Vare, P.; Scott, W. Learning for a Change: Exploring the Relationship Between Education and Sustainable Development. J. Educ. Sustain. Dev. 2007, 1, 191-198. [CrossRef]

13. Wals, A.E.J. A Mid-DESD Review: Key findings and ways forward. J. Educ. Sustain. Dev. 2009, 3, $195-204$. [CrossRef]

14. Wals, A.E.J. Shaping the Education of Tomorrow: 2012 Full-length Report on the UN Decade of Education for Sustainable Development; UNESCO: Paris, France, 2012.

15. United Nations General Assembly 70/1. Transforming Our World: The 2030 Agenda for Sustainable Development; UNESCO: Paris, France, 2015. Available online: https://sustainabledevelopment.un.org/content/documents/ 21252030\%20Agenda\%20for\%20Sustainable\%20Development\%20web.pdf (accessed on 25 April 2020).

16. UNESCO. 206 EX/6.II Annex. Education for Sustainable Development: Towards Achieving the SDGs (ESD for 2030); UNESCO: Paris, France, 2019. Available online: https://unesdoc.unesco.org/ark:/48223/pf0000366797. locale $=$ en (accessed on 25 April 2020).

17. Brent Edwards, D., Jr.; Sustarsic, M.; Chiba, M.; McCormick, M.; Goo, M.; Perriton, S. Achieving and Monitoring Education for Sustainable Development and Global Citizenship: A Systematic Review of the Literature. Sustainability 2020, 12, 1383. [CrossRef]

18. Singer-Brodowski, M.; von Seggern, J.; Duveneck, A.; Etzkorn, N. Moving (Reflexively within) Structures. The Governance of Education for Sustainable Development in Germany. Sustainability 2020, 12, 2778. [CrossRef]

19. Nationale Plattform Bildung für nachhaltige Entwicklung c/o Bundesministerium für Bildung und Forschung Referat Bildung in Regionen; Bildung für nachhaltige Entwicklung [National Platform Education for Sustainable Development c/o Federal Ministry of Education and Research]. National Action Plan on Education for Sustainable Development. 2017. Available online: https://www.bmbf.de/files/BMBF_NAP_ BNE_EN_Screen.pdf (accessed on 25 April 2020).

20. Tilbury, D.; Janousek, S. Development of a National Approach to Monitoring, Assessment and Reporting on the Decade of Education for Sustainable Development: Summarising Documented Experiences on the Development of ESD Indicators and Networking with Expert Groups on ESD Indicators; Australian Research Institute of Education for Sustainability and Australian Government Department of the Environment and Water Resources: Sydney, Australia, 2006.

21. Stepanek Lockhart, A. Monitoring ESD: Lessons learned and ways forward. In Issues and Trends in Education for Sustainable Development; Leicht, A., Heiss, J., Byun, W.J., Eds.; UNESCO: Paris, France, 2018; pp. $215-231$.

22. Nazir, J.; Pedretti, E.; Wallace, J.; Montemurro, D.; Inwood, H. Climate Change and Sustainable Development: The Response from Education. The Canadian Perspective. 2009. Available online: https:/www.researchgate.net/publication/233095616_Reflections_on_the_Canadian_Experience_ With_Education_for_Climate_Change_and_Sustainable_Development (accessed on 25 April 2020).

23. Tomas, L.; Mills, R.; Rigano, D.; Sandhu, M. Education for sustainable development in the senior earth and environmental science syllabus in Queensland, Australia. Aust. J. Environ. Educ. 2020, 36, 44-62. [CrossRef]

24. Kanapathy, S.; Lee, K.E.; Sivapalan, S.; Mokhtar, M.; Syed Zakaria, S.Z.; Mohd Zahidi, A. Sustainable development concept in the chemistry curriculum: An exploration of foundation students' perspective. Int. J. Sustain. High. Educ. 2019, 20, 2-22. [CrossRef]

25. Dube, C. The Uptake of Education for Sustainable Development in Geography Curricula in South African Secondary Schools. In Schooling for Sustainable Development in Africa; Lotz-Sisitka, H., Shumba, O., Lupele, J., Wilmot, D., Eds.; Springer International Publishing: Cham, Switzerland, 2017; pp. 93-105, ISBN 978-3-319-45989-9.

26. Sule, O.F.; Greig, A. Embedding Education for Sustainable Development (ESD) Within the Curriculum of UK Higher Educational Institutions (HEIs): Strategic Priorities. In Sustainable Development Research at Universities in the United Kingdom: Approaches, Methods and Projects; Leal Filho, W., Ed.; Springer International Publishing: Cham, Switzerland, 2017; pp. 91-107, ISBN 978-3-319-47883-8. 
27. Beveridge, D.; McKenzie, M.; Aikens, K.; Strobbe, K. A National Census of Sustainability in K-12 Education Policy: Implications for International Monitoring, Evaluation, and Research. Can. J. Educ. Adm. Policy 2019, 188, 36-52.

28. Gorichanaz, T.; Latham, K.F. Document phenomenology: A framework for holistic analysis. J. Doc. 2016, 72, 1114-1133. [CrossRef]

29. Stevenson, R.B. Schooling and environmental/sustainability education: From discourses of policy and practice to discourses of professional learning. Environ. Educ. Res. 2007, 13, 265-285. [CrossRef]

30. Pavlova, M. Curriculum Development for ESD Through Technology and Vocational Education. In Technology and Vocational Education for Sustainable Development. Empowering Individuals for the Future; Pavlova, M., Ed.; Springer: Dordrecht, The Netherlands, 2009; pp. 87-103, ISBN 978-1-4020-5279-8.

31. Fredriksson, U.; Kusanagi, K.N.; Gougoulakis, P.; Matsuda, Y.; Kitamura, Y. A Comparative Study of Curriculums for Education for Sustainable Development (ESD) in Sweden and Japan. Sustainability 2020, 12, 1123. [CrossRef]

32. Wals, A.E.J.; Blewitt, J. Third-wave Sustainability in Highter Education: Some (Inter)national Trends and Developments. In Sustainability Education: Perspectives and Practice Across Higher Education; Jones, P., Selby, D., Sterling, S., Eds.; Earthscan: London, UK, 2010; pp. 55-74, ISBN 978-1-84407-878-3.

33. Hedefalk, M.; Almqvist, J.; Östman, L. Education for sustainable development in early childhood education: A review of the research literature. Environ. Educ. Res. 2014, 21, 975-990. [CrossRef]

34. Singer-Brodowski, M.; Brock, A.; Etzkorn, N.; Otte, I. Monitoring of education for sustainable development in Germany-Insights from early childhood education, school and higher education. Environ. Educ. Res. 2018, 25, 492-507. [CrossRef]

35. Brock, A.; de Haan, G.; Etzkorn, N.; Singer-Brodowski, M. Wegmarken zur Transformation-Nationales Monitoring von Bildung für nachhaltige Entwicklung in Deutschland; [Waymarks towards TransformationNational Monitoring of Education for Sustainable Development in Germany]; Verlag Barbara Budrich: Berlin, Germany; Toronto, ON, Canada, 2018.

36. Bolden, R.; Moscarlola, J. Bridging the Quantitative-Qualitative Divide. The Lexical Approach to Textual Data Analysis. Soc. Sci. Comput. Rev. 2000, 18, 450-460. [CrossRef]

37. Döbert, H.; Weishaupt, H. Bildungsmonitoring. In Schul- und Unterrichtsreform durch ergebnisorientierte Steuerung: Empirische Befunde und forschungsmethodische Implikationen; Wacker, A., Maier, U., Wissinger, J., Eds.; VS Verlag für Sozialwissenschaften: Wiesbaden, Germany, 2012; pp. 155-173, ISBN 978-3-531-94183-7.

38. Rürup, M.; Fuchs, H.-W.; Weishaupt, H. Bildungsberichterstattung-Bildungsmonitoring. In Handbuch Neue Steuerung im Schulsystem; [Education monitoring. In School and Teaching Reform through Results-Oriented Steering: Empirical Findings and Implication for Research Methodology]; Altrichter, H., Maag Merki, K., Eds.; Springer: Wiesbaden, Germany, 2016; pp. 377-401.

39. Michelsen, G.; Adomßent, M.; Bormann, I.; Burandt, S.; Fischbach, R. Indikatoren der Bildung für nachhaltige Entwicklung-Ein Werkstattbericht [Education for Sustainable Development Indicators-A Workshop Report]; Deutsche UNESCO-Kommission e.V. (DUK), VAS-Verlag, 2011. Available online: https://www.bneportal.de/sites/default/files/Indikatoren_2520der_2520BNE.File_0.pdf (accessed on 25 April 2020).

40. UNECE (United Nations Economic Commission for Europe). Indicators for Education for Sustainable Development. Progress Report on the Work of the Expert Group. ECE/CEP/AC.13/2006/5. 2006. Available online: https://digitallibrary.un.org/record/580720?ln=en (accessed on 25 April 2020).

41. UNECE (United Nations Economic Commission for Europe). Report on the UNECE Steering Committee on Education for Sustainable Development on its Third Meeting; United Nations Economic Commission for Europe: Geneva, Switzerland, 2008.

42. Singer-Brodowski, M.; Etzkorn, N.; von Seggern, J. One Transformation Path Does Not Fit All-Insights into the Diffusion Processes of Education for Sustainable Development in Different Educational Areas in Germany. Sustainability 2019, 11, 269. [CrossRef]

43. Brock, A. Verankerung von Bildung für nachhaltige Entwicklung im Bildungsbereich Schule. In Wegmarken zur Transformation -Nationales Monitoring von Bildung für nachhaltige Entwicklung in Deutschland; [Anchoring Education for Sustainable Development in the School Education Sector. In Waymarks towards Transformation-National Monitoring of Education for Sustainable Development in Germany]; Brock, A., de Haan, G., Etzkorn, N., Singer-Brodowski, M., Eds.; Verlag Barbara Budrich: Berlin, Germany; Toronto, ON, Canada, 2018; pp. 67-118. 
44. Etzkorn, N.; Singer-Brodowski, M. Verankerung von Bildung für nachhaltige Entwicklung im Bildungsbereich Hochschule. In Wegmarken zur Transformation-Nationales Monitoring von Bildung für nachhaltige Entwicklung in Deutschland; [Anchoring Education for Sustainable Development in the University Education Sector. In Waymarks towards Transformation-National Monitoring of Education for Sustainable Development in Germany]; Brock, A., de Haan, G., Etzkorn, N., Singer-Brodowski, M., Eds.; Verlag Barbara Budrich: Berlin, Germany; Toronto, ON, Canada, 2018; pp. 189-230.

45. Waltner, E.-M.; Rieß, W.; Brock, A. Development of an ESD Indicator for Teacher Training and the National Monitoring for ESD Implementation in Germany. Sustainability 2018, 10, 2508. [CrossRef]

46. Spall, S. Peer Debriefing in Qualitative Research: Emerging Operational Models. Qual. Inq. 1998, 4, $280-292$. [CrossRef]

47. Lincoln, Y.S.; Guba, E.G. Naturalistic Inquiry; Sage Publications, Inc.: Beverly Hills, CA, USA, 1985.

48. Pramling Samuelsson, I. Why We Should Begin Early with ESD: The Role of Early Childhood Education. Int. J. Early Child. 2011, 43, 103-118. [CrossRef]

49. Singer-Brodowski, M. Bildung für nachhaltige Entwicklung in der frühkindlichen Bildung. In Pfade der Transformation. Die Verbreitung von Bildung für nachhaltige Entwicklung im deutschen Bildungssystem; [Education for Sustainable Development in Early Childhood Education. In Paths of Transformation. The Spread of Education for Sustainable Development in the German Education System]; Singer-Brodowski, M., Etzkorn, N., Grapentin-Rimek, T., Eds.; Verlag Barbara Budrich: Opladen/Berlin, Germany; Toronto, ON, Canada, 2019; pp. 65-100.

50. Singer-Brodowski, M. Verankerung von Bildung für nachhaltige Entwicklung in der Frühkindlichen Bildung. In Wegmarken zur Transformation-Nationales Monitoring von Bildung für nachhaltige Entwicklung in Deutschland; [Anchoring Education for Sustainable Development in Early Childhood Education. In Waymarks towards Transformation - National Monitoring of Education for Sustainable Development in Germany]; Brock, A., de Haan, G., Etzkorn, N., Singer-Brodowski, M., Eds.; Verlag Barbara Budrich: Berlin, Germany; Toronto, ON, Canada, 2018; pp. 35-66.

51. Ministerium für Bildung Rheinland-Pfalz [Rhineland-Palatinate Ministry of Education]. Bildungs- und Erziehungsempfehlungen des Landes Rheinland-Pfalz plus Qualitätsempfehlungen [Educational Recommendations of the State of Rhineland-Palatinate plus Quality Recommendations], 4th ed.; Cornelsen Verlag GmbH: Berlin, Germany, 2018; ISBN 978-3-589-24862-9.

52. Arnold, M.-T.; Carnap, A.; Bormann, I. Bestandsaufnahme zur Verankerung von Bildung für nachhaltige Entwicklung in Bildungs- und Lehrplänen [Anchoring Education for Sustainable Development in Education and Curricula: A Survey]. 2016. Available online: https://www.haus-der-kleinen-forscher.de/fileadmin/ Redaktion/4_Ueber_Uns/Evaluation/Abgeschlossene_Studien/170301_BNE_Expertise.pdf (accessed on 25 April 2020).

53. Ständige Konferenz der Kultusminister der Länder in der Bundesrepublik Deutschland (KMK) [Standing Conference of the Ministers of Education and Cultural Affairs]; Deutsche UNESCO-Kommission (DUK) [German Commission for UNESCO]. Empfehlung vom 15.06.2007 zur “Bildung für nachhaltige Entwicklung in der Schule" [Recommendation of 15.06.2007 on "Education for Sustainable Development in Schools"]. 2007.

54. Ständige Konferenz der Kultusminister der Länder in der Bundesrepublik Deutschland (KMK) [Standing Conference of the Ministers of Education and Cultural Affairs]. Zur Situation und zu Perspektiven der Bildung für nachhaltige Entwicklung. Bericht der Kultusministerkonferenz vom 17.03.2017 [On the Situation and Perspectives of Education for Sustainable Development-Report of the Conference of the Ministers of Education and Cultural Affairs of 17.03.2017]. 2017. Available online: https://www.kmk.org/ fileadmin/Dateien/veroeffentlichungen_beschluesse/2017/2017_03_17-Bericht-BNE-2017.pdf (accessed on 25 April 2020).

55. Diettrich, A.; Hahne, K.; Winzier, D. Vocational education and training for sustainable development: Backgrounds, activities, initial results. BWP Spec. Issue 2009 2009, 53-58. Available online: https: //www.bibb.de/dokumente_archiv/pdf/a12bwp_special-edition_2009_diettrich_hahne_winzier.pdf (accessed on 25 April 2020).

56. Ertl, H. The Concept of Modularisation in Vocational Education and Training: The Debate in Germany and Its Implications. Oxf. Rev. Educ. 2002, 28, 53-73. [CrossRef] 
57. Bundesministerium für Bildung und Forschung [Federal Ministry of Education and Research]. Berufsbildungsbericht 2018 [Vocational Training Report 2018]; Federal Ministry of Education and Research: Bonn, Germany, 2018.

58. Bundesinstitut für Berufsbildung (BIBB) [Federal Institute for Vocational Education and Training]. Datenreport zum Berufsbildungsbericht 2018. Informationen und Analysen zur Entwicklung der beruflichen Bildung [Data Report on the Report on Vocational Education and Training 2018 Information and Analyses of the Development of Vocational Education and Training]; Federal Institute for Vocational Education and Training: Bonn, Germany, 2018.

59. Kultusministerkonferenz [Standing Conference of the Ministers of Education and Cultural Affairs]. Kompetenzorientiertes Qualifikationsprofil für die Ausbildung von Erzieherinnen und Erziehern an Fachschulen und Fachakademien (Beschluss der Kultusministerkonferenz vom 01.12.2011 i.d.F. vom 24.11.2017) [Competence-Oriented Qualification Profile for the Training of Pre-School Educators at Technical Schools and Colleges (Resolution of the Conference of the Ministers of Education and Cultural Affairs of 01.12.2011, as amended on 24.11.2017)]. 2017. Available online: https://www.kmk.org/fileadmin/Dateien/ veroeffentlichungen_beschluesse/2011/2011_12_01-ErzieherInnen-QualiProfil.pdf (accessed on 25 April 2020).

60. Sekretariat der Kultusministerkonferenz [Secretariat of the Standing Conference of the Ministers of Education and Cultural Affairs]. Handreichung für die Erarbeitung von Rahmenlehrplänen der Kultusministerkonferenz für den berufsbezogenen Unterricht in der Berufsschule und ihre Abstimmung mit Ausbildungsordnungen des Bundes für anerkannte Ausbildungsberufe [Handbook for the Development of Framework Curricula of the Standing Conference of the Ministers of Education and Cultural Affairs (KMK) for Work-Related Instruction in Vocational Schools and their Coordination with Federal Training Regulations for Recognised Apprenticed Professions]; Secretariat of the Standing Conference of the Ministers of Education and Cultural Affairs: Berlin, Germany, 2018.

61. Otte, I.; Singer-Brodowski, M. Verankerung von Bildung für nachhaltige Entwicklung in der dualen beruflichen Ausbildung. In Wegmarken zur Transformation-Nationales Monitoring von Bildung für nachhaltige Entwicklung in Deutschland; [Anchoring Education for Sustainable Development in Dual Vocational Education. In Waymarks towards Transformation-National Monitoring of Education for Sustainable Development in Germany]; Brock, A., de Haan, G., Etzkorn, N., Singer-Brodowski (Hrsg.), M., Eds.; Verlag Barbara Budrich: Berlin, Germany; Toronto, ON, Canada, 2018; pp. 117-188.

62. Singer-Brodowski, M.; Grapentin-Rimek, T. Bildung für nachhaltige Entwicklung in der beruflichen Bildung. In Pfade der Transformation. Die Verbreitung von Bildung für nachhaltige Entwicklung im Deutschen Bildungssystem; [Education for Sustainable Development in Vocational Education. In Paths of Transformation. The Diffusion of Education for Sustainable Development in the German Education System]; Singer-Brodowski, M., Etzkorn, N., Grapentin-Rimek, T., Eds.; Verlag Barbara Budrich: Opladen/Berlin, Germany; Toronto, ON, Canada, 2019; pp. 143-192.

63. Bundesinstitut für Berufsbildung [Federal Institute for Vocational Education and Training]. Verzeichnis der anerkannten Ausbildungsberufe 2019 [List of Recognized Apprenticed Professions 2019]. 2019. Available online: https://www.unternehmen-integrieren-fluechtlinge.de/wp-content/uploads/2020/01/verzeichnis_ anerkannter_ausbildungsberufe_2019.pdf (accessed on 25 April 2020).

64. Hochschulrektorenkonferenz (HRK) [German Rectors' Conference]. Empfehlung der 25. Mitgliederversammlung der HRK am 06. November 2018 in Lüneburg. Für eine Kultur der Nachhaltigkeit [Recommendation of the 25th HRK General Assembly on 6 November 2018 in Lüneburg. For a Culture of Sustainability]; Hochschulrektorenkonferenz: Berlin/Bonn, Germany, 2018.

65. Etzkorn, N. Bildung für nachhaltige Entwicklung in Hochschulen. In Pfade der Transformation. Die Verbreitung von Bildung für nachhaltige Entwicklung im deutschen Bildungssystem; [Education for Sustainable Development in Universities. In Paths of Transformation. The Diffusion of Education for Sustainable Development in the German Education System]; Singer-Brodowski, M., Etzkorn, N., Grapentin-Rimek, T., Eds.; Verlag Barbara Budrich: Opladen/Berlin, Germany; Toronto, ON, Canada, 2019; pp. 193-232.

66. Ministerium für Wissenschaft Forschung und Kultur des Landes Brandenburg; (MWFK) [Ministry of Science, Research and Culture of the State of Brandenburg]. Hochschulvertrag. MWFK-Universität Potsdam [University Contract. MWFK-University of Potsdam]. 2019. Available online: https://mwfk.brandenburg. de/sixcms/media.php/9/HSV_UNIP_2019.pdf (accessed on 25 April 2020).

67. Weldemariam, K.; Boyd, D.; Hirst, N.; Sageidet, B.M.; Browder, J.K.; Grogan, L.; Hughes, F. A Critical Analysis of Concepts Associated with Sustainability in Early Childhood Curriculum Frameworks Across Five National Contexts. Int. J. Early Child. 2017. [CrossRef] 
68. Ärlemalm-Hagsér, E.; Sandberg, A. Sustainable development in early childhood education: In- service students' comprehension of the concept. Environ. Educ. Res. 2011, 17, 187-200. [CrossRef]

69. UNESCO. Progress on Education for Sustainable Development and Global Citizenship Education: Findings of the 6th Consultation on the Implementation of the 1974 Recommendation Concerning Education for International Understanding, Co-Operation and Peace and Education; UNESCO: Paris, France, 2018. Available online: https://unesdoc.unesco.org/ark:/48223/pf0000266176 (accessed on 25 April 2020).

70. DUK. Vom Projekt zur Struktur: Strategiepapier der Arbeitsgruppe "Berufliche Aus- und Weiterbildung" des Runden Tisches der UN-Dekade "Bildung für nachhaltige Entwicklung" [From Project to Structure: Strategy Paper of the Working Group on Vocational Education and Training of the Round Table of the UN Decade of Education for Sustainable Development]; DUK: Bonn, Germany, 2014. Available online: https://www.bne-portal.de/sites/default/files/downloads/publikationen/DUK\%20-\%20Projekt\% 20zur\%20Struktur\%20AG\%20Berufliche\%20Aus-\%20und\%20Weiterbildung.pdf (accessed on 25 April 2020).

71. Arenas, A.; Londoño, F. Connecting Vocational and Technical Education with Sustainability. In International Handbook of Research on Environmental Education; Stevenson, R.B., Brody, M., Dillon, J., Wals, A.E.J., Eds.; Routledge: New York, NY, USA, 2013; ISBN 9781136699313.

72. Pavlova, M. Green Skills as the Agenda for the Competence Movement in Vocational and Professional Education. In Competence-Based Vocational and Professional Education: Bridging the Worlds of Work and Education; Mulder, M., Ed.; Springer International Publishing: Cham, Switzerland, 2017; pp. 931-951, ISBN 978-3-319-41713-4.

73. McGrath, S.; Powell, L. Skills for sustainable development: Transforming vocational education and training beyond 2015. Int. J. Educ. Dev. 2016, 50, 12-19. [CrossRef]

74. UNESCO. Transforming Technical and Vocational Education and Training: Building Skills for Work and Life. Background Report for the UNESCO World Congress on TVET; UNESCO: Paris, France, 2012.

75. Caeiro, S.; Azeiteiro, U.M.; Filho, W.L.; Jabbour, C. Sustainability Assessment Tools in Higher Education Institutions: Mapping Trends and Good Practices Around the World; Springer: Basel, Switzerland, 2013; ISBN 9783319023755.

76. Schneidewind, U.; Singer-Brodowski, M.; Augenstein, K.; Stelzer, F. Pledge for a Transformative Science: A Conceptual Framework; Wuppertal Institute for Climate, Environment and Energy: Wuppertal, Germany, 2016; Volume 191.

77. Alonso-Almeida, M.D.M.; Marimon, F.; Casani, F.; Rodriguez-Pomeda, J. Diffusion of sustainability reporting in universities: Current situation and future perspectives. J. Clean. Prod. 2015, 106, 144-154. [CrossRef]

78. Barth, M. Many roads lead to sustainability: A process-oriented analysis of change in higher education. Int. J. Sustain. High. Educ. 2013, 14, 160-175. [CrossRef]

79. Ilieva, R.; Beck, K.; Waterstone, B. Towards sustainable internationalisation of higher education. High. Educ. 2014, 68, 875-889. [CrossRef]

(C) 2020 by the authors. Licensee MDPI, Basel, Switzerland. This article is an open access article distributed under the terms and conditions of the Creative Commons Attribution (CC BY) license (http://creativecommons.org/licenses/by/4.0/). 